\title{
Master by Any Other Means
}

\author{
BETSEY B. PRICE
}

This article ${ }^{1}$ is an out-growth of an earlier one, "Paired in Ceremony" which discussed recognizable similaritics between particular rituals in late Medieval academic guilds and craft guilds. There the components of the ritual of inception, in the academic guild, and reception, in the craft guild, were examined in detail. Despite their eventually different names, inception and reception were, in each case, the rituals by which the guild determined individuals to be eligible for mastership (through prerequisites) and embraced the eligible candidates within the guild as masters (through ceremony). The two guilds' rituals were clearly composed of an analogous assortment of elements, and hence are appropriately seen as paired in terms of their ceremony. There are, however, clear indications that over the course of the Medieval and Renaissance periods not all of the analogous components of the two ceremonies were simultaneously present nor had the same importance for each type of guild at the same point in time.

The particular focus in this article is the question of whether guilds of the Middle Ages and Renaissance really, that is, more than ceremoniously, determined who could function as a master. Was guild recognition through the inception or reception ritual the only means by which one became acknowledged as competent and able to pursue one's profession in the particular areas of academic or craft performance? The tack taken to attempt to answer this question will derive from the earlier discussion of mastership rituals. The rituals themselves, it is posited, can provide clues to the importance of the guilds in defining effective mastership, particularly through an analysis of the relative prominence of each ritual's different components. What is at issue is change in the relative strength of the guild to assert itself vis-à-vis external authority in determining the significance of guild mastership. The general conclusion to be reached is that both the University and the craft guild controlled, to degrees varying over time, the responsibility for determining both those who could hold the title of master,

Renaissance and Reformation / Renaissance et Réforme, XXV, 1 (1989) 115 


\section{6 / Renaissance and Reformation}

and the importance of that guild title. The extent of a guild's power in both respects is reflected in the specific importance given to various components of its rituals of mastership.

In the present article, the analysis to evaluate changes in the capacity of guilds to determine mastership will be undertaken in terms of a "most elaborate" posture of ritualized guild sclf-expression in the case of each guild. ${ }^{3}$ After this "most elaborate" posture is described, the discussion will turn to tracing chronologically changes in the ritualized posture of the University and craft guilds. The chart of ritual changes will, it is argued, reflect the course of the guild's ability to assume responsibility for its members, to determine eligibility for mastership and to give weight to the title. The discussion of ritual changes will extend from the twelfth century to the state of guilds in the sixteenth century, the phase of guild maturity. Some brief reflections about changes in the concept and function of the guilds will follow and lead to the conclusion that changes in the elaborateness of mastership rituals indeed mirrored changes that were taking place in the function of the guilds vis-à-vis their own members and external authorities.

\section{Guild Inception/Reception Rituals}

The inception or reception ritual was a guild's way of designating a master as such. This ritual whether of the academic or the craft guild illustrated the concern of the guild to regulate "rights and privileges among its members." 4 The ritual was, however, also a reflection of how those rights and privileges could be (or had been) formulated, demonstrated and reinforced in the posturing of the guild vis-à-vis the outside world. The picture of the "most elaborate" inception and reception rituals which emerges from primary documents, particularly those of their directives, is one of practices which by the thirtecnth century had three characteristics: 1) they were solidified in writing, 2) they were widely practiced to some degree in all types of guilds, and 3) they were significant in the recognition of a new master in the guilds. As to their particular aspects, the guild rituals of inception and reception were composed of two distinct parts. One part comprised the prerequisites for becoming a member of the guild. In a second part, the rituals of acknowledgement by the guild members of the candidate as a new master took place. Although the analysis here will begin with the part concerning the necessary prerequisites, that part ought not be 
considered necessarily first, neither in terms of chronological presence nor in the relative importance of the two parts to one another.

\section{Prerequisites}

Prerequisites were those conditions which were established, in principle, for the purpose of determining the eligibility of a candidate to become a master. In the two different guilds, the University guild and the craft guild, the role of prerequisites in determining mastership is quite different, as is the evolution of that role. The types of prerequisites are, however, remarkably similar in each of the guilds:

\section{TABLE I}

Inception Ritual Reception Ritual

Prerequisites:
a) Training - $\begin{aligned} & \text { student } \\ & \text { teacher }\end{aligned}$
Training - apprentice
b) Testimony
free(wo)man/journey(wo)man
c) Examination
Testimony
d) License granted
Examination/"Chef d'oeuvre"
e) Oath sworn
Guild seat or Mastership purchased
Oath sworn

The "most elaborate" form of each of these prerequisites will be discussed separately.

a) Training: The training requirements to become a University masters candidate is explicitly stated in most University statutes. ${ }^{5}$ The "most elaborate" stipulations reveal that according to University guild requirements any candidate for the title of master had to have completed two distinct periods of training. The first was a set period of study, a certain part of which was to be completed under one master. The second was a specified period of teaching during which the student practice-taught under a master's supervision. While the required length of each of these periods varied from university to university and from time to time, ${ }^{6}$ the fact that one finds in some primary documents requirements (such as which courses a student must take when or the particular conditions under which the teaching exercise was to be considered adequate) spelled out in detail reflects the significance the training was thought to have as a prerequisite for mastership. 
Among the "most elaborate" prerequisites for craft guild mastership was also stipulated training in two distinct phases: as apprentice and as free(wo)man or journey(wo)man. While the apprenticeship period differed depending on the trade, most sets of guild directives contained the explicit requirement that the guild's trainees undertake this phase of learning the craft under a master. ${ }^{7}$ Once the apprentice had completed an initial term of training, he/she became a journey(wo)man or free(wo)man, that is, free to travel to learn further, to hire out as a wage labourer or to practice the trade by starting a business. While the activities of the would-be master were not specifically stipulated for the time to be spent as free(wo)man, constraints on the range of undertakings defined it clearly as a significant rite of passage. Not yet a master, the crafts(wo)man would not, for example, be permitted during the time as a journey(wo)man or free(wo)man to engage an apprentice. 8

b) Testimony: After his training the University student would make known his intention to become licensed to teach. On his behalf then depositions or testimony as to the student's "fittedness" for candidacy would be collected from the masters of his faculty and from others. At its "most elaborate" point this prerequisite is explicitly stated in most University statutes. Its serious significance is reflectcd by the number of witnesses and amount of time involved in the procedure. At one time in the arts faculty at Oxford, for example, a total of 15 people were to offer testimony; ${ }^{9}$ once at Cambridge all the masters of a particular faculty may have had to testify; ${ }^{10}$ at Paris, after a student made application for the license, a period of three months was designated for receiving depositions from masters and "other serious and instructed persons." 11

In the case of the craft guilds, once the individual had completed the training phases, he/she could seck permission of the head of the particular craft, a Grand Master/Mistress, to have his/her preparedness for the mastership assessed. The individual would thus petition for testimony to establish that the requirements for apprenticeship had indeed been fulfilled ${ }^{12}$ and that he/she was financially and otherwise capable of professional service.

c) Examination: A further prerequisite on the road to obtaining the rank of University master was the passing of one or more examinations. Depending on the date and location, the examinations took these possible general forms: closed examinations before onc's superiors and/or public examinations open to all. ${ }^{13}$ Just as the form of the examinations varied, so 
too did their timing in a student's career. The "most elaborate" examination prerequisite entailed multiple exams which defined specific phases: a "determination" and disputation for the bachelor's candidate, as well as the magisterial examination. These sets of exams were to be separated from one another by a stipulated three-year period. ${ }^{14}$

An examination was not a universal requirement for progression to craft mastership. As references are found in many guild statutes to the serious testing of a master's candidate, there seems, however, to be nothing barring the inclusion of the exam in a "most elaborate" profile of the reception ritual. The craft guild exam seems to have served one of three different purposes: 1) it was occasionally employed to establish that the candidate had acquired sufficient training to lcave his apprenticeship before its term was up; ${ }^{15}$ 2) it could be used to corroborate the testimony given concerning the length of a candidate's training; 3 ) it could verify the quality of training received by a candidate unknown to those of the guild into which he/she sought entry. In each case the examination was aimed at confirming that the candidate thoroughly knew the craft. Its "most elaborate" stipulations were that specific skills be exhibited ${ }^{16}$ without counsel or aide of anyone and under the scrutiny of designated masters. ${ }^{17}$

Furthermore at some point many craft guilds began to require of all masters candidates specific evidence of expertise, that is, a "chef d'oeuvre." 18 Like the craft guild examination, the type of work to demonstrate accomplishment might be stipulated either by guild statute or by certain masters. When complete, it would be presented to particular judges or to the whole assembly of masters for approval as "good and meet."

d) License/Purchased mastership: Successful completion of the University masters examination was followed by the granting of the teaching license. The University guild's inception ritual recognized the holding of the teaching license as a necessary prerequisite.

In the case of the craft guilds primary documents reveal the almost universal importance of an analogous, but essentially financial, prerequisite for obtaining membership. The first article of many guild statutes immediately identified the guild as accessible either through a "free" or a purchased mastership. ${ }^{19}$ In the instance of the so-called "free" guilds, mastership was available to any trained candidate who could prove that he/she had adequate financial resources to undertake the craft. The capital required varied enormously from craft to craft. The statutory stipulation by the Parisian millers' guild that every master be able to buy or rent a mill was 
among the most onerous. ${ }^{20}$ Every "free" candidate had to offer guarantees that his means and his wisdom were sufficient ("si saige et si riches") to maintain his business and an apprentice during a whole training period. ${ }^{21}$

Masterships of the non-"free" crafts entailed the actual buying of the business. In addition to that largest monetary consideration craft mastership entailed, the "most claborate" craft guild requirements had candidates also paying a number of smaller fees, e.g., examination and guild entry fees. Already at the apprentice level entrance fees were often demanded of those whose families were not members of the guild.

e) Oath: A final prerequisite in the University guilds was the obligatory oath of obedience. This oath was frequently preserved word for word in University guild directives. Its words are especially revealing as to the manner of allegiance and obedience the guild deemed important. Through the "most elaborate" oaths the University masters candidate swore allegiance to the statutes of the particular institution and to its pertinent subgroups (e.g., the nation meaning a group of kinsmen by a convention of geographical designation and/or the faculty in which he would become a master). ${ }^{22}$ Interestingly too, he also swore both initially as an inceptor and then later as a master to respect the formalities of the inception ceremony itself: its dress code, the rigours of its ceremony, its recognized forms of celebration, etc.

The candidate for master status in a craft guild also had to take a requisite oath of obedience. The oath, found in written directives, was to be sworn before guild members on a saint's relics or a "book," usually the Gospels. Extremely comprehensive in its "most claborate" form, the oath contained the list of behaviours the guild demanded of its members: e.g., to work faithfully and well, to observe the guild's statutes, to give honour and respect to the elders, to keep guild secrets. ${ }^{23}$

\section{Ceremony}

The other part of the ritual for conferring mastership was the ceremonial acknowledgement by the group of masters that the candidate had indeed fulfilled the prerequisites for eligibility for mastership and would thenceforth be part of the group of masters. This was the actual ceremony of inception or reception: As was the case with mastership prerequisites, the role and components of the formal inception and reception ceremonies also underwent change differently within the two type of guilds. Again both types of guilds, the University and the craft guild, will be examined, here in light 
of the "most elaborate" ceremonial posture of the University guild's inception and the craft guild's reception.

\title{
TABLE II
}

\section{Inception Ritual Reception Ritual}

\section{Ceremony:}

f) Disputation/Lecture

g) Symbols of office

h) Blessing/Kiss of Peace

i) Banquet

\author{
Questioning \\ Symbolic entry \\ Kiss of Peace \\ Toast
}

Before addressing the individual components of the ceremony it would be perhaps appropriate to sketch the setting for the event. In the case of the University, once the prerequisites had been met, the candidate was given permission to extend an invitation to the masters to attend his inception ceremony. The "most elaborate" University guild directives indicate where the inception gathering was to be held and when it was to take place. Usually invited and present, wearing the stipulated academic regalia, ${ }^{24}$ was the group of all masters, junior and senior, from the faculty (or "college," in the case of Bologna), in which the candidate had been trained, e.g., arts, theology, medicine or law. The group was variously referred to as the society of masters, the fellowship of the elect masters, the collegium, masters' association, masters' consortium, guild or college. It was of this group that the successful candidate would become a member.

In the case of the craft guild, the statutes reflect that the magisterial reception was a gathering at which all the members of the guild would be present. In some guilds the reception was held only once a year. Unlike the University ceremony it was an occasion at which more than one candidate could be promoted to master.

f) Disputation/Questioning: The first part of the University inception ceremony was a two-stage ceremonial performance. A formal disputation followed by a ceremonial lecture by the incepting candidate emulated ceremoniously the duties he would be expected to undertake as regent master. ${ }^{25}$

Most frequently the disputation, called Vespers, was held (except during Lent) at the hour of vespers in the evening of the day before the candidate was actually to be received by the masters. In the morning of the day after 
Vespers the candidate would deliver his inaugural lecture. While the lecture format was relatively straightforward, the disputation proceeded according to a complex pattern of "principal and secondary arguments, propositions, suppositions, responsions, oppositions, replications, and conclusions" 26 stipulated in part by guild directives. As evidence of the importarce of this part of the inception ritual, information on disputation particulars can in fact be found in all three of the main types of primary documents related to the inception ritual: in University guild directives, but also in the books of the official record keeper of the guild, ${ }^{27}$ and in contemporary reports of inceptions. ${ }^{28}$

Although the abstract skills of disputation and lecturing were not essential to the professions of the craft guilds, an analogous mock grilling seems to have been held. The candidate would stand outside the door of the house of the Grand Master to answer questions of guild tradition ("questions d'usage" 29 ) addressed by the masters.

g) Symbols of office/Symbolic entry: Either before or after the University lecture, the presiding master, under whose direction the candidate had prepared and undergone his license examination presented the candidate with several symbols of his new office: ${ }^{30}$ the "book," opened symbolically, a golden ring placed on his finger, and the cap of the master placed on his head. ${ }^{31}$ In some ceremonies the candidate took his seat with his fellow masters upon the magisterial cathedra. ${ }^{32}$

Several ceremonial acts of the craft guild reception were analogous to the academic symbolic bestowing of magisterial office. The symbolic passage of the candidate into the group of masters took the form of the candidate's exuberant breaking of a pot against a wall, ${ }^{33}$ a formal granting to the candidate the authority to take on an apprentice, or a ceremonial procession to the house of the Grand Master and admittance therein after the answering of the formal questions.

h) Blessing/Kiss of Peace: In the University inception ceremony, after completion of the candidate's lecture and the bestowing of the symbols of academic office, the presiding master would close the ceremony "most elaborately" with the blessing or conferring of membership on behalf of all the masters, a benediction and the kiss of peace. In the craft guild, the kiss of peace was one of the symbolic signs of a candidate's entry into the guild.

i) Banquet/Toast: The formal inception rituals of the University guild were followed by the typical Medieval cclcbration, a banquet. ${ }^{34}$ It was given by the newly incepted master to his new associates, usually at a tavern. The banquets were in some periods extremely elaborate, including festive food, drink and attire, all provided for many guests, ${ }^{35}$ as well as lavish entertainment, such as 
choreae in Paris and Bologna, ${ }^{36}$ or the corrida de toros in Salamanca. There were also obligatory gifts to professors, performers, and officials, stipulated often as fixed money payments or as a certain kind or quality of good. ${ }^{37}$

The reception "banquet" of the craft guild was really the raising of a glass symbolically. Each craft guild had its own tradition. A toast to the new candidate might be made at the house of the Grand Master when all had entered "for the wine and the fire." ${ }^{38}$ Sometimes the masters each contributed a certain small amount of money to pay for the libations; in other cases the candidate himself shouldered the cost of drink for all. ${ }^{39}$

\section{Changes in Guild Rituals}

To assist in the discussion of the changes in University and craft guild rituals of inception and reception, a schematic representation of the components of the respective rituals will be set out. The lettering is chosen to reflect the degree to which the respective guild determined the component in question as important in the ritual:

CAPITALS indicate elaborate guild ritual and involvement in the activity; Lower Case indicates that guild rituals had only a moderate bearing on the activity;

$<$ Lower Case> indicates that the activity was carried out, but either not by the guild itself or not specifically in relation to the mastership ritual; indicates a modification to the ritual not discussed above.

Its discussion is identified by $\left(^{*}\right)$ in the text below; indicates no place for the component in the guild mastership ritual.

\section{TABLE III}

\begin{tabular}{|c|c|c|c|}
\hline \multicolumn{2}{|c|}{ Inception Ritual ${ }^{40}$} & \multicolumn{2}{|c|}{ Reception Ritual } \\
\hline c. $1215^{41}$ & after $1318^{42}$ & late 13 th & late 14 th \\
\hline \multicolumn{4}{|l|}{ Prerequisites: } \\
\hline Training & $<$ Training $>$ & Training* & $<$ Training $>$ \\
\hline TESTIMONY & Testimony & Testimony & Testimony* \\
\hline Examination & $<$ Examination $>$ & EXAMINATION & CHEF D'OEUVRE \\
\hline$<$ License>* & $<$ License $>^{*}$ & Payment & $<$ Payment $>$ \\
\hline OATH $^{*}$ & OATH $^{*}$ & OATH & OATH \\
\hline
\end{tabular}


Ceremony:

DISPUTATION

DISPUTATION

LECTURE

LECTURE

SYMBOLS OF OFFICE Symbols of Office KISS OF PEACE

BANQUET KISS OF PEACE BANQUET

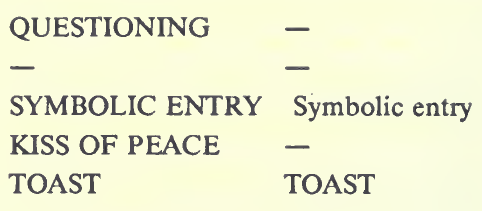

\section{Early Inception Ritual}

The Medieval University came into being in the late twelfth century and University guilds acquired an independent status acknowledged by University constitution or statutes over the course of the thirteenth century. Inception was an enunciated part of University life at Bologna by 1215 , at Montpelier by 1220 , at Salerno by 1231 , at Cambridge by 1245 , in the English-German nation at the University of Paris by 1252, and at Oxford University before 1253.43

In the early period of the University guild, as Table III above reflects, predominant importance was placed on the ceremonial way a new master would become part of the guild. Some of the components of the ceremony were actually fixed in University statutes from the very recognition of the guild organization, e.g., the right of the masters to bind their members by oath. ${ }^{44}$ Almost as early, the other ceremonial components appear to have been fully devised and conducted according to the will of the guild.

As for the prerequisites to University mastership, however, only the giving of testimony on behalf of a candidate entailed an elaborate ritual. This is not to say that the University guild designated no role to prerequisites in the inception process. They were clearly known to the guild and formally recognized by it in their statutory form. They were, however, out of the exclusive control of the masters. Once formalized in University statutes, prerequisites for mastership such as a minimum age and specific amount of lecturing experience were for the most part beyond the discretion of the guild masters. 45

$\left(^{*}\right)$ The inception component which most dramatically reflects a weak role for the guild is the granting of the teaching license. In the cathedral schools of the eleventh and twelfth century the head masters, responsible for appointing the teaching staff, would often exact payment from candidates for the teaching privilege and its accompanying license. Early University statutes were written to exclude such "reprehensible" practices. The privilege of licensing was removed from the exclusive sphere of the 
masters and given to the head of the university, the Chancellor, an episcopal or royal appointee. In addition, by 1233 the license to teach conferred formally on its holder the right to teach at any university, and thereby in principle it lost its significant connection to any particular university or university guild. (*) Already in regulations for the arts faculty at Paris drawn up in 1215, precautions against losing all new masters to other institutions and professions were being taken by obliging a new master to remain in the faculty to teach for two years after inception; at Oxford the same condition held. ${ }^{46}$

Licensing per se was not in the hands of the University guild and not therefore a prerequisite of the guild's making. ${ }^{47}$ It was realized, however, by the University guild that it could not ignore the practice of licensing, and so defined its prerequisites around it. In order to be permitted to incept a candidate had to have met two conditions: receipt of the license with the approval of the masters and recognition from the masters of his stature. The first condition meant that the masters established their own stipulations for proper training and proper examinations; the second condition was implemented through the procedure of testimony which, as mentioned above, was quite elaborate. The masters made a further statement about their own interests in designating the distinct purpose for the inception ritual as the giving of a guild title, not the conferring of the University degree. $^{48}$

\section{Early Reception Rituals}

The initial ritualized posture of the craft guild in its acknowledgement of mastership was not really very different from that of the University guild. In the thirteenth century the craft guild also put strong emphasis on the ceremonial half of reception ( $c f$. Table III). The whole group of masters was so much in favour of a closing celebration that it provided the entertainment budget.

Again like the University guild, measured in terms of elaborate ritual, the ceremonial parts of reception outweighed the importance given by the guild to the determination of prerequisites. Craft guilds faced some of the same constraints to determining their own prerequisites for mastership as did the University guilds. They were, if not the property of a king or lord, at least under a legal jurisdiction which was interested in revenues from guild activities. To buy a mastership (analogous to obtaining a teaching license) was not always to fulfil a prerequisite stipulated by the guild masters; 
ofttimes the money transaction was dictated by the king. ${ }^{49}$ The purchasing transaction was so important that, in the case of some guilds, mastership was defined as "the business," not as a personal title. This meant that without the business, one was no longer a "master." ${ }^{0}$ Again as in the case of the University guild, the craft masters came to distinguish the honour they conferred as different from the honour acquired by fulfilling externally imposed prerequisites. Like the University masters, the craft guild masters did not deny that an individual could buy a business. The sale of masterships and the subsequent identifying of the mastership with the business itself, however, led to the use of a different word, "prud'homme," to designate the mastership the guild bestowed, that is, the title of the individual holding a guild mastership and running a business. ${ }^{51}$ The craft guild found itself forced to employ a new title to give its members an identity distinct from that dictated by mastership purchase and to safeguard its role of bestower of titles.

The craft guild's external authority expected still more fiscal return from them than the occasional payment for mastership purchase. In an attempt to guarantee the best return in the form of taxes ${ }^{52}$ and fines for infractions of guild statutes, ${ }^{53}$ the authority sought to regulate guild activities. This included the presumed need to screen candidates for guild membership and to inspect guild merchandise..$^{54}$

Thus a witnessed list of the candidates adopted by the guild for approbation as masters was submitted compliantly to the authority for approval, ${ }^{55}$ and hardly received (or deserved) an claborate guild ritual. Nor even did the stipulations for guild training receive much detail in Medieval guild documents. ${ }^{56}$

Apparently vigorous interest was shown by the craft guilds in the prerequisite of examination. Given the otherwise lackluster guild rituals connected with craft guild prerequisites, this anomalous enthusiasm of examination does require explanation. Lespinasse and Bonnardot, the editors of Boileau's Livre des metiers, written 1260-1270, interpret all the reception rigours imposed by the guild, among which they quite rightly include the examination, as signs of magisterial ill-will and restriction. ${ }^{57}$ In light of the fact, however, that the early craft guilds (like the University guilds) were well aware of the power of their external authorities, it seems plausible that the guilds "chose" to implement their own examination prerequisites to demonstrate their "good-will" to regulate themselves..$^{58}$ It is true that the guilds imposed elaborate examinations on candidates in which 
the specific skills to be exhibited would be performed under the scrutiny of Jurors and that Jurors were indeed representatives of external authority. At the same time, however, it must be remembered that these same Jurors were still members of the guild. ${ }^{59}$ This is not to say that the guilds did not adopt some of the tactics of external authority. Fees were demanded for every known service provided by and for guild members: e.g., house fees, that is, payments to the officers of the guild, ${ }^{60}$ night-watchman fees, ${ }^{61}$ not to mention $\left(^{*}\right)$ guild entrance fees exacted already at the apprenticeship level.

\section{Later Reception Rituals}

By the late fourteenth century the craft guild reception ritual had undergone changes to reach a profile different from that of the late Medieval University inception. The ceremonial parts of reception, which, however elaborate, had been held all along usually once a year at one of the guild semi-annual meetings, now formed a very small part of even its ritualized preoccupations. Of the earlier important components only the oath and the toast remained. Rituals of symbolic entry, already fading in importance during the thirteenth century, are virtually ignored, and the burden of defraying the costs of the reception toast has shifted to the candidate. ${ }^{62}$ Only the oath still retained elaborate form and importance. 63

What did acquire further claboration in the fourtecnth century was, however, the examination prerequisite. It now took the form of the chef d'oeuvre, mentioned earlier. ${ }^{64}$ The chef d'oeuvre, a demonstration of the accomplished level of the candidate in his craft, became the means by which a candidate was judged qualified. Once it was approved, the guild's representatives of external authority, the Jurors, would make an oral request to representatives of royal or scigniorial justice for recognition of the candidate. $\left({ }^{*}\right)$ This testimonial on the candidate's behalf, which now followed the examination, would also include a witness to the candidate's character. It seems that by this time the external authorities, king or other, rarely had to exercise their titular control over the choice of masters candidates. For all appearances they let themselves be guided by the recommendations of the guild, ${ }^{65}$ but those recommendations were based on prerequisites, as mentioned earlier, already radically determined by those same authorities.

In the rise of the craft guild, any number of craftsmen had been permitted to carry on the trade, provided that each one joined and submitted to the 
organization created for the purpose of regulating it. By the fourteenth century, however, craft guilds were seen to be restricting the number of practitioners in the profession both by limiting the number of guild members and by prohibiting all non-members from practicing. This trend continued well through the sixteenth century. It has been argued as well that in order to begin to limit the number of guild members practicing the profession that the guild assumed responsibility for enforcing, if not re-defining prerequisites for mastership.

The shift in importance of specific rituals of craft guild reception from the late thirteenth to the late fourteenth century seems to indicate that it became less possible to buy one's way into a guild. One had now to prove that one had the qualifications for becoming a member in the guild, meaning not only financial qualifications. While the importance of prerequisites which confirmed the candidate's skill steadily increased, simultaneously the ceremonial aspects of mastership fell into relative insignificance, and in fact became mere frills to obtaining master status within the guild.

\section{Later Inception Rituals}

In the case of the University inception ritual slightly different changes occurred between the mid-thirteenth and the mid-fourteenth century. Most components of the ceremonial part of the ritual remained important: the oath, the disputation and official lecture, the kiss of peace and the banquet. Many of the ceremonial activities, such as Vespers ${ }^{66}$ and the banquet festivities became more elaborate than ever. ${ }^{67}$ The oath and symbols of office, however, both came to incorporate features dictated by external authority: e.g., the swearing of obedience to the head of the university, ${ }^{68}$ and the receiving of certain symbols from a university authority rather than the presiding master. The whole ceremonial ritual would not in fact have taken place without the presence of representatives of University administration, e.g., the Chancellor or the Proctor at Oxford, at Paris the Rector, the Proctor or the Proctor's chief agent, the head Beadle. ${ }^{69}$

Components of the prerequisite part of the inception ritual also underwent some change. The guild masters added new prerequisites to those already in place which had become over time usurped or compromised by external authorities. $\left({ }^{*}\right)$ It was required by the guild, for example, that for mastership additional books be "heard" beyond those already required for the teaching license. ${ }^{70}\left({ }^{*}\right)$ In some instances before a candidate was 
permitted to swear the oath, he had to receive separate permission from his nation. ${ }^{71}$

Briefly, in its inception ceremony the University masters guild continued to place strong emphasis on the oaths which a master had to swear. The guild's own new ways of stipulating the necessary conditions for mastership took on importance due to the emphasis placed on the older conditions enforced now by external authoritics.

\section{Guild Assertion}

The changes in the University and craft guilds' strategies to assert their importance vis-à-vis external authority are manifest in their attempts to acquire greater responsibility for specific parts of the inception/reception ritual. The University masters attempted to affirm their strength vis-à-vis the external authority of the Church by maintaining the relatively strong emphasis on the ceremonial parts of the inception ritual, and in a sense thereby, trying to diminish the importance of the full set of inception prerequisites. The craft guild, on the other hand, increasingly assumed responsibility over the implementation of prerequisites for their masters candidates and diminished its emphasis on the ceremonial adoption of a new master. From the fifteenth into the sixteenth century both guilds continued their respective later emphasis. Interestingly enough, however, the conditions which determined that emphasis had changed.

In the cases of both the Medieval University guild and craft guilds, the authority they had been striving so hard to assert became ever further reduced. Their own response to challenges to their authority was, however, no longer one of adopting a new posture within the ritual of mastership. Instead the two guilds simply procecded to acknowledge as little as possible the authority of any external source. In the case of the craft guild, the external authority of State or Church drew the guild farther away from an independent economic status, to the point that not only were the prerequisites of craft guild mastership not determined within the guild, but even its own posture vis-à-vis external authority was defined by others. Other means to craft guild mastership had made real inroads.

In the case of the University guilds, it was an external authority, which without further dictating prerequisites for mastership, came, nonetheless, to determine who should do the teaching. This was accomplished through economic compensation, that is, by paying salaries to individuals who were deemed by external authority to be adequate "masters." The University guild 
in effect lost not only its ability to stipulate who could be a master, but even its power to exclude from employ those whom it deemed unqualified. If not really an independent means to mastership, the chance to be employed as a teacher, nonetheless, could now derive from a source outside of the University itself.

As each of these guilds reached its post-Medieval maturity, the emphasis it had placed on different aspects of the ceremony did not change. The fact that the guilds ceased to respond in terms of their mastership rituals to the changing circumstances of their existence bespeaks a fundamental change in the role of the ritual within the guild, and perhaps in the role of the guild itself. What the whole of the inception or reception ritual came to represent is something quite different from the original concept and function of the respective guild.

\section{Guild Function Authority Changes: Conclusion}

Initially, guilds tried to establish a power and an independent function vis-à-vis other institutions which might have answered the same needs, that is the institution of the Church or the State. The power the guilds tried to exercise was the power over the day-to-day activities of their own members and hence over the activity of all guilds affairs. The functions the guilds tried to serve were many. These functions were intended, however, in every case to respond to or make of the institution of the guild a necessity in the lives of its masters and all those at work in the same profession. It tried, for example, to assist in the emergency of its members, to strengthen administratively the body of those exercising the profession through the election of officers or the stipulating of status. It tried to retain power for its members vis-à-vis the city or the Church, that is, to demand recognition, new privileges or concessions of external authorities. It attempted both to educate and train its members or at the very least, to stipulate the education and training of members who could be acknowledged as masters, and lastly to grant the freedom to exercise the profession to those who had attained the required level of expertise.

Over time both the University and the craft guild tried to hang on to both their power and their function, but as changes in the rituals of inception and reception reflect, their ability to do so changed a great deal. It is surprising, however, that the real indicator of a major late Medieval/early Renaissance change in guild power and function is the lack of further change in mastership ritual. The fluctuations in the emphasis the guilds 
placed on different parts of their mastership rituals during the Middle Ages reflect the importance the ritual had for the guild in its posture vis-à-vis its own members as well as vis-à-vis the outside world. The late Medieval ritual, however, which ceased to undergo further major changes, appeared as it were immune to external influence. No longer responsive, the guild ritual of mastership ceased to be a mirror of the ability of the guild to assert itself vis-à-vis external authority and in that posture to assume responsibility for the screening of the candidates to the guild and their capacity to exercise their profession as members of that guild.

\section{York University}

\section{Notes}

1 Correspondence and discussions with O.F.H. and Lykke Pedersen have enhanced this paper. I thank them both.

2 To be published in the forthcoming festschrift in honour of the late Professor John Bruckman, Glendon College, York University (ed. A. Baudot, Toronto: GREF).

3 Some liberty has, however, perforce, been taken in an effort to establish a) from the many Medieval University and craft guilds a generalizable position for "the" University guild and "the" craft guild and b) one complete "most elaborate" posture, which was done by unifying the most elaborate states of each individual component of the ritual, no matter when they occurred between the 12th and 16th centuries.

4 Cf. G. Leff, Paris and Oxford Universities in the Thirteenth and Fourteenth Centuries (New York: John Wiley and Sons, Inc., 1968), p. 2.

5 E.g., in those of Paris from 1215 on: edited by H. Denifle in the Chartularium Universitatis Parisiensis (Paris: 1899, repr. Bruxelles: Culture and Civilization, 1964), Tomes 1-3, and by H. Denifle and A. Chartelain in the Auctarium Chartularii Universitatis Parisiensis (Paris: Fratres Delalain, 1894, re-ed. 1937). In those of Oxford from 1253: as edited by S. Gibson in the Statuta Antiqua Universitatis Oxoniensis (Oxford: Clarendon Press, 1931). Cf. also Leff, Paris and Oxford Universities, p. 26 and H. Rashdall, The Universities of Europe in the Middle Ages (Oxford: Clarendon Press, 1895, re-ed. 1935), vol. 3, pp. 148-49.

6 At one time at the university of Montpellier the "teaching" period was required to be no longer than one month! Cf. Les Statuts et priviliges des universités françaises depuis leur fondation jusqu'en 1789, ed. M. Fournier (Paris: L. Larose et Forcel, 1891), tome 2, p. 5.

7 E.g., all but four of the 130 craft guilds in Paris in 1260-1270 noted in their directives a required apprenticeship. The exceptions there were the "Mesuruers, Jaugeurs, Criers de vin, agants du Parloirs aux Bourgeois": see E. Boileau, Les Métiers et Corporations de la Ville de Paris, eds. R. de Lespinasse and F. Bonnardot (Paris: Imprimerie Nationale, 1879), p. c. For minimum required periods of apprenticeship in the Parisian craft guilds, $c f$. ibid., p. cii, in. 1.

8 E.g., Statuts des Corroiers (Paris), Boileau, Les Métiers, Tit. LXXXVII, art. XI or the statutes of a silk spinsters' guild (Paris), L. Martines, Not in God's Image (New York: Harper and Row, 1973), pp. 155-56.

9 Cf. Statuta, ed. cit., pp. 29-30, 11. 24-05.

10 Cf. M.B. Hackett, The Original Statutes of Cambridge University (Cambridge: Cambridge University Press, 1970), p. 122, [n. 1.

11 Cf. Leff, Paris and Oxford Universities, p. 168.

12 Boileau, Les Métiers, p. cix. 


\section{2 / Renaissance and Reformation}

13 Some historians draw attention to the difficulty in making general statements about these examinations, given their extended use in time and geography: e.g., L.J. Daly, The Medieval University 1200-1400 (New York: Sheed and Ward, 1961), p. 134.

14 Such was depicted to have been the case at Oxford according to its statutes of the first decade of the fifteenth century. Cf. Leff, Paris and Oxford Universities, pp. $149 \mathrm{ff}$. and Daly, The Medieval University, pp. 122 ff.

15 E.g., Statuts des Orfevres, Boileau, Les Métiers, Tit. XI, art. III.

16 E.g., Statuts des Fourreurs de Chapeaux: "fourrer de touz poins un chapel," ibid., Tit. XI, art. III; Statuts des Tailleurs de robes: "de coudre et de couper," ibid., Tit. LVI, art. III.

17 E.g, Statuts des Cordouaniers: "les gardes du mestier," ibid., Tit. LXXXIV, art. X; Statuts des Ouvriers en Draps de soie: "les mestes qui le mestier gardent de par le Roy," ibid., Tit. LXXXIV, art. X.

18 Cf. for Paris, ibid., p. cx: for Chartres, G. Aclocque. Les corporations, lindustrie et la commerce a Chartres du XIe siècle à la révolution (Paris: Mazel et Plancher, 1917, repr. New York: Burt Franklin, 1967), pp. 41-45; for Languedoc, A. Gouron, La réglementation des métiers en Languedoc au moyen áge (Paris: Librairie Minard. 1958), pp. 251-52.

19 "Il puet estre Cordier a Paris qui veut, c'est a savoir faisierres des cordes de toutes manieres de fil, de teill, poil, pour tant que il sache le mestier, et il a de quoi, et pour tant que il euvre aus us et aus coustumes del mestier," Boileau, Les Métiers, Tit. XIII, art. I.

20 Ibid., Tit. II, art. I.

21 E.g., Statuts des Boucliers (quoted), ibid., Tit. XXI, art. VII; Statuts des Tisserands, Tit. L, art. XVII.

22 Cf. e.g., "articuli quos tenentur jurare bachellarii in artibus incepturi" (Paris, circa 1280), Chart., ed. cit., I. No. 501; Oxford (after 1253), Statuta, ed. cit., p. 19; Oxford (before 1350), ibid., p. 35.

23 For examples of craft guild oaths, $c f$. Ordinances of the Gild of St. Katherine, Stamford (12th century), T. Smith, English Gilds (London: Oxford University Press, 1870, repr. 1963), pp. 189-90, and pp. 191-92 re date; Statuts des Meuniers, Boileau, Les Métiers, Tit. II, art. VIIII.

24 Cf., at Paris, Chart., ed. cit., I, No. 20; at Cambridge, Hackett, The Original Statutes, p. 147. The clerical tonsure was stipulated as part of the appropriate attire for inceptions at the faculty of medicine at Montpellier, cf. Statuts, ed. cit., p. 5a.

25 "Incipere fuit primam lectionem magistralem legere." Auctarium, I, xxxi. The practice may derive from Roman law, i.e., "the actual investiture of an official with his office," Rashdall, The Universities of Europe, vol. 1, p. 285.

26 Hackett, The Original Statutes, p. 127. There were wide differences from university to university and from time to time in the length and complexity of formats used, e.g., Cambridge, $c f$. ibid., pp. 129-30.

27 Cf. "Liber procuratorum" in G.C. Boyce, The English-German Nation in the University of Paris during the Middle Ages (Bruges: St. Catherine Press, Ltd., 1927).

$28 C f$. "Quaestiones disputatae" in A.G. Little and F. Pelster, Oxford Theology and Theologians c. A.D. 1282-1302 (Oxford: Clarendon Press, 1934), e.g. p. v and p. 49, fn. 5.

29 Boileau, Les Métiers, p. cxv.

30 These were the universal symbols of the University inception. These were occasionally further "elaborated" by a "closed book that he [the new master] may have that science close and familiar in mind and may keep it sealed from the unworthy and in such respects as it is not expedient to reveal," Antonino, "Summa" in L. Thorndike, University Records and Life in the Middle Ages (New York: Columbia University Press: 1944, repr. 1949), p. 309. A new master of grammar at Oxford would receive, among other things, a "palmer" and a birch and proceed ceremoniously to flog a boy: Rashdall, The Universities of Europe, vol. 3, p. 347. 
31 Depending on the faculty, the cap was either the pileum or the biretta. Hence the name birettatio sometimes given to this part of the inception ceremony: ibid., vol. 1, p. 485.

32 This may have been quite specific to certain universities and faculties, such as at Bologna and Cambridge.

33 E.g., Statuts des Talemeliers [Boulangers]. Boileau, Les Métiers, Tit. I, art. XIII.

34 At Cambridge inceptions the banquet was at one time celebrated on the night of Vespers, before the principium or lecture the following morning! Hackett, The Original Statutes, p. 126, p. 199, iii.

35 Cf. G. Comparye, Abelard and the Origin and Early History of Universities (New York: Charles Scribner's Sons, 1907), pp. 161-63.

36 The extent to and frequency with which the choreae were frowned upon bespeaks the role in played in University celebrations. They were banned from Paris inceptions (Chart., ed. cit., I, No. 202 (dated 1252), No 501 (dated 1280)) and from those of Bologna (Statuta, ed. cit., p. 116 cited by Rashdall, The Universities of Europe, vol. 1, p. 230, fn. 1).

37 E.g., at Pisa, a $1 \mathrm{lb}$. box of comfits to each doctor; at Bologna, $12 \mathrm{lb}$. 10s. to the archdeacon; at Toulouse, 8 grossi to the mummers, a pair of gloves to each doctor. Cf. Rashdall, The Universities of Europe, vol. 1, pp. 229-30, fn. 2.

38 Boileau, Les Métiers, p. cxv.

39 Ibid., p. cxvi.

40 This schema will be most consistently representative of the guilds at the University of Paris. It is events there which determined the dates chosen.

41 Date of the first University statutes (Paris) to fix masters' rights.

421318 is a demarcation date for Paris; the oath of obedience to the rector, the head of the university, came to be imposed on all teaching there.

43 For more information on the inception at Bologna, $c f$. Helene Wieruszowski, The Medieval University. Masters, Students, Learning (Princeton: D. Van Nostrand Company, Inc., 1966), p. 68; at Montpelier, cf. Statuts, II, No. 882; at Salerno, $c f$. Wieruszowski, pp. 77-78; at Cambridge, $c f$. Hackett, The Original Statutes, pp. 126 and 40; at Paris, $c f$. Leff, Paris and Oxford Universities, p. 147; and at Oxford, cf. Leff, p. 169 and Wieruszowski, p. 54.

44 Leff, Paris and Oxford Universities, p. 26.

45 The exceptions to this rule were the Oxford masters. $\Lambda t$ Oxford. from 1214 on, it fell to a Chancellor to confer licenses and titles. Over time, however, as extremely detailed conditions for mastership became codified, the masters continued to exercise strong control over candidates. The complexity of requirements led to the almost universal practice of a masters candidate requesting of the regent masters an exemption or "grace" from some of them; "at last it was supposed that it was the assembly of regents [not the Chancellor] who really conferred the degree," Rashdall, The Universities of Europe, vol. 3, p. 148. Cf. also Statuta, ed. cit., pp. cxviii-cxxii.

46 Leff, Paris and Oxford Universities, pp. 138 and 160.

$47 \mathrm{G}$. Post argues that both the practice of licensing and masters forming into guilds arose independent of one another: "Alexander III, the Licentia Docendi, and the Rise of the Universities," in Anniversary Essays in Medieval IIistory, ed. C.H. Taylor Freeport (New York: Books for Libraries Press, Inc., 1929, repr. 1967), p. 275.

48 The actual title conferred would have been the highest one attainable, either magister or doctor depending on the faculty. Throughout the Middle Ages these titles were neither consistently nor clearly distinguished. Cf. Comparye, Abelard, pp. 157-58.

49 The guild statutes where this would be stipulated were drafted at the behest of the banal authority; e.g., "Nus ne puet estre Regratiers de pain a Paris, c'est savoir venderes de pain que autres fourniece et quise, se il ne achate le mestier du Roy," Boileau, Les Métiers, Tit. IX, art. I. 


\section{4 / Renaissance and Reformation}

$50 \mathrm{Ibid}$. p. cxvii. It also seems to have meant that children whose mothers or fathers held masterships were exempt from repurchase of (the same) one for themselves. Ibid., p. cx.

51 Cf. A. Gouron, La réglementation, pp. 243-44.

52 Boileau, Les Métiers, p. cxviii, pp. cxxxvi-cxli.

53 Ibid., pp. cxxvi-cxxvii.

54 Candidates would have to swear to permit inspection of their wares when taking the guild's oath.

55 "Sauf a nostre Seingneur lou Roi et au prevost de Paris de ajouster et de oster, de crestre et de amenuisier en ces choses desus dites toutes foiz qu'il leur plera et il verront que bien soit et profit au mestier et au commun du peuple." Statuts des Chaussiers, Boileau, Les Métiers, Tit. LV, art. X.

56 An exception may have been spotted by Etienne Martin Saint-Leon, Ilistoire des corporations de métiers depuis leurs origines jusqu'à leur suppression en 1791 (Paris: Librairie Félix Alcam, 1922), p. 114, fn. 2: the celebration of guild mastership was not to be granted until four years of success in the business had been accomplished.

57 Boileau, Les Métiers, pp. cxiv-cxv.

58 Ibid., pp. cxxxv-cxxxvi.

59 "les gardes du mestier," Statuts des Cordouaniers, Boileau, Les Métiers, Tit. LXXXIV, art. X; "les mestres qui le mestier gardent de par le Roy," Statuts des Ouvriers en Draps de soie, ibid., Tit. LXXXIV, art. X. Jurors came to their post either by royal designation or by internal guild election: ibid., pp. cxviii-cxix.

60 E.g., Smith, English Gilds, pp. 54-55 and 108-109.

61 Boileau, Les Métiers, p. cxli-cxliv.

62 Ibid., p. cxvi.

63 Right up until the seventeenth century, $c f$. those collected by G. Aclocque, Les corporations.

64 The practice of an examination in the form of the chef d'oeuvre seems to have begun in the early fourteenth century. Cf. Boileau, Les Métiers, p. cx; G. Aclocque, Les corporations, pp. 41-45; and Gouron, La réglementation, pp. 251-52.

65 Boileau, Les Métiers, p. xcvii and cxv.

66 True to the maxim that ceremonies tend to become more complex, longer and more detailed over time are examples from Heidelberg. Ingolstadt and Bologna: $c f$. Rashdall, The Universities of Europe, p. 486, fn. 1; and H. Wieruszowski, The Medieval University, p. 32 respectively.

67 The regulation limits placed on the amount a candidate might spend on his inception festivities went unheeded and bans on certain festive activities had to be frequently repeated. Cf. Daly, The Medieval University, p. 144; Rashdall, The Universities of Europe, vol. 3, p. 489, fn. 1; and Chart., ed. cit., I. No. 202 [dated 1252], No. 501 [dated 1280].

68 Wieruszowski, The Medieval University, p. 49.

69 Boyce, The English-German Nation, p. 61: P. Kibre, The Nations in the Medieval Universities (Cambridge: Medieval Academy of America. 1962), pp. 75 I.; Chart. ed. cit., I, No. 418.

70 This was technically not the case at Paris until 1366: Chart. ed. cit. III, No. 1319.

71 Rashdall, The Universities of Europe, vol. 1, p. 461. 